\section{Australian Journal of \\ Crop Science}

\title{
Characteristics of quince fruits cultivars' (Cydonia oblonga Mill.) grown in Brazil
}

\author{
Magali Leonel $^{1 *}$, Sarita Leonel ${ }^{2}$, Marco António Tecchio ${ }^{2}$, Martha Maria Mischan ${ }^{3}$, Mara Fernandes \\ Moura $^{4}$, Diego Xavier ${ }^{4}$
}

${ }^{1}$ Center for Tropical Roots and Starches (CERAT), São Paulo State University (UNESP), Botucatu, São Paulo, 18610-307, Brazil

${ }^{2}$ Department of Horticulture, College of Agricultural Sciences (FCA), São Paulo State University (UNESP), Botucatu, São Paulo, Brazil

${ }^{3}$ Departament of Biostatistic, Bioscience Institute (IBB), São Paulo State University (UNESP), Botucatu, São Paulo, Brazil

${ }^{4}$ Fruit Center, Campinas Agronomic Institute (IAC), Jundiaí, São Paulo, 13214-820, Brazil

\section{*Corresponding author: mleonel@cerat.unesp.br}

\begin{abstract}
The fruits of quinces are mostly used to produce food and functional products. Studies on this fruit have increased recently aiming to increase the use of quince fruit as industrial raw material. The present study aimed to evaluate ten different cultivars of quince grown in São Paulo state, Brazil, regarding weight, transverse and longitudinal diameter, skin and pulp color, firmness, $\mathrm{pH}$, acidity, moisture, ash, starch, lipids, fiber and total sugars of fruits, aiming to provide important information to the industrial applicability. Significant differences were observed between the cultivars for the analyzed parameters. The relationship between transverse and longitudinal diameters of fruits showed mainly globular shape. Analyzing the firmness of the fruits' pulp it was observed semi-hard pulp. The fruits analyzed were appropriate for consumption and have potential for application in industrial processing.
\end{abstract}

Keywords: Cydonia oblonga Mill, weight, color, firmness, nutritional composition.

Abreviations: CV_coefficient of variation; LSD_least significant difference; SD_standard deviation; W_weight; TD_transverse diameter; LD_longitudinal diameter; F_firmness.

\section{Introduction}

Brazil is the world's third largest fruit producer with an output of about 42 million tons in 2011 included in this production twenty species produced in the country in a cultivated area of about 1.9 million hectares. The main producing areas in Brazil are Southeast, Northeast and South. In 2010, the State of São Paulo accounted for $32.9 \%$ of the national supply of fresh fruit. The temperate fruit trees are distributed in eleven of the twenty-six Brazilian states. The state of Rio Grande do Sul accounts for approximately $49.3 \%$ of the total produced in the country, followed by the states of Santa Catarina (23.2\%), São Paulo (10.3\%), Paraná (6.2\%), Pernambuco (5.3\%), Bahia (3.0\%) and Minas Gerais (1.8\%). In addition to these states, the temperate fruit are present in the state of Rio de Janeiro, Paraiba, Mato Grosso and Goiás The most produced fruits are in descending order: grape, apple, peach, persimmon, fig, pear and quince, and the total growth in the period of 1999 to 2009 was $43.5 \%$ (Fachinelo et al., 2011). The quince, Cydonia oblonga Mill., is a member of the Rosaceae family. Originally from the Caucasus region its cultivation later spread to Europe and Mediterranean countries. The species was introduced into Brazil in 1532, brought by colonizers (Silva and Oliveira, 2013).

Quince in the unripe phase is not much appreciated for fresh consumption because of the hardness, bitterness and astringency of the pulp, however, when ripe has nice flavor. Quince intended mainly for marmalade, jam, jelly and cake and is characterized by a low fat content and as a major source of organic acids, sugars, fiber, and minerals such as potassium, phosphorus and calcium, as well as, as source of functional components, such as phenolic compounds with antioxidant activity. It is known to have hypoglycemic action, anti-inflammatory, antimicrobial, anticancer, anti-allergic and antiulcer and act as a tonic for the heart and brain, and a inhibitor of alpha-amylase, which reflects the great potential of this fruit as a raw material for food and pharmaceutical industries (Rodríguez-Guisado et al., 2009; Khoubnasabjafari and Jouyban, 2011; Koutb and Morsy, 2012; Legua et al., 2013; Silva and Oliveira, 2013, Szychowski et al., 2014, Wojdyło et al., 2014). The quince culture had in the last 10 years a decrease of $85.01 \%$ in the harvested area and $80.02 \%$ in production. Currently, the Brazilian states with the highest production are Minas Gerais, Bahia and Rio Grande do Sul. The probable causes of these declines are due to the small use of quince as an industrial raw material and the low consumption of fruit in natura (Fachinelo et al., 2011). Given the importance of this cultivation for national fruit growing, especially for small scale rural producers, where growing quince is a highly profitable alternative, several studies have been developed with the aim of removing obstacles to its development, as well as its use as raw material in industry (Alvarenga et al., 2008, Pio et al., 2009, Pereira et al., 2011). Fruit quality is attributed to its physical characteristics, which correspond to the external appearance, highlighting the size, the shape of the fruit and the color of the shell. Such 
characteristics are factors of fruits acceptability by consumers. When the fruits are transported and marketed occur changes in texture, represented by progressive loss of firmness, and of shell color, due to the degradation of chlorophyll as well as, by the synthesis of other pigments, attributes used to evaluate the quality and ripening of fruits.

Associated with these attributes, the composition of the fruit is also very important in view of the presence of various chemical constituents in the pulp. It is this intrinsic quality it offers to the fruits and their derivative products organoleptic and nutritional qualities responsible for final acceptance in the market as well as being a determining factor for use as industrial raw material.

Thus, the aim of this study was to evaluate ten cultivars of quince originating from the active germplasm bank, Fruit Center, Agricultural Institute of Campinas (IAC) in Jundiaí, São Paulo state, according to their physical, physic-chemical and chemical characteristics.

\section{Results and Discussion}

\section{Physical characteristics of quince fruits}

Data analysis showed differences between the cultivars for the variables analyzed (Tables 1, 2 and 3). Variation in the weight (W) of fruit between the cultivars has been reported in other studies of quince, probably due to edaphoclimatic differences in the locations they were cultivated, as well as in the management technique used. In general, the weight of the quinces was below those reported by Bettiol Neto et al. (2011). The mean weight of the fruit was also below those reported in Rodrígues-Guisado et al. (2009) and Légua et al. (2013) evaluating quinces in Spain. This result may be due to the climatic conditions in the years of cultivation.

As for the shape of the quinces, data analysis showed differences between the cultivars studied for these variables, with the smallest mean transverse diameter (TD) found for fruit of 'De Patras' (Table 1). The data show the morphology of the fruit to be globular and oval, with the ratio of transverse and longitudinal diameter (LD) close to 1.0 (varying from 1.16 'Smyrna' to 1.35 Rea's Mammouth'). The results observed are close to those reported by Rodríguez-Guisado et al. (2009) when analyzing the morphological aspects of quince cultivated in Spain, and stated that the majority of fruit were globular, with a minimum equatorial diameter ranging from 73.23 to 83.85 $\mathrm{mm}$ and maximum equatorial diameter varying between 74.53 and $86.07 \mathrm{~mm}$.

The firmness of the fruit is an attribute that may indicate the ripeness or point of harvest and influences its sale. Thus, fruits that are not firm are less resistant to transport, storing and handling (Fagundes and Yamanishi, 2001).

The results showed a variation between 52 and $79.6 \mathrm{~N}$ (5.3 to $8.12 \mathrm{Kgf} \mathrm{cm}^{2}$ ) for fruit firmness (F), with the highest values observed in the Cheldow, Portugal, Provence, IAC- CHA 13 and Mendoza Inta 37 strains (Table 1). The values found were similar to those reported by Bettiol Neto et al. (2011) for quinces, as well as to those reported by RodríguesGuisado et al. (2009) who reported firmness of 7.17 to 9.31 Kgf $\mathrm{cm}^{2}$.

Gunes (2003), evaluating the firmness of 'Cukurgobek' and 'Esme' quince, cultivated in two periods observed decreased firmness as they ripened, reporting values of 105.4 to $70.2 \mathrm{~N}$ for 'Esme' and 113.0 to $81.4 \mathrm{~N}$ for 'Cukurgobek'.

In fresh fruit, the color of the skin is an indicator of quality, freshness, flavor and ripeness. Analyzing variables in quince skin color it were observed differences between cultivars, namely, all the fruit had green ( $\mathrm{a}^{*}$ negative) and yellow ( $\mathrm{b}^{*}$ positive), with the highest $b^{*}$ for the 'De Patras' (Table 2). A yellow coloration is favorable for sales, being the sought after tone in quince, customers preferring their fruit to be quite yellow. Luminosity of the quince skin varied between 68.6 and 81.3. These values exceed those observed by Bettiol Neto et al. (2011), who reported luminosity of 65.37 to 73.29 .

As for the relationship with pulp color the results showed that the fruits were characterized as having light pulp (luminosity above 74 ) of a predominantly yellow tone ( $b^{*}$ varying from 28.8 to 35.1 ) and with some green ( $\mathrm{a}^{*}$ ranging from -1.8 to 0.9 ). The cluster analysis to the physical characteristics of quince fruit showed that the 50 cultivar's replicates were separated in $n=3$ clusters with 15,24 and 11 replicates each. Multivariate F statistic for Wilks' Lambda was significant ( $p$ $<0.0001)$ and the clusters were well differentiated. The more important variables in differentiating the clusters were weight, firmness and longitudinal diameter with coefficients of determination $\mathrm{R} 2=0.574,0.537,0.534$, respectively.

Considering these variables we see that the cluster 1 , with three cultivars, is characterized by high values for weight and longitudinal diameter. Cluster 2, with 5 cultivars, have low values of weight and longitudinal diameter. Cluster 3 , has cultivars with high levels of weight and low of firmness (Fig $1)$.

\section{Physical and chemical composition of quinces}

Determining the chemical composition of quince is of great importance in studies into its nutritional aspects and use as raw material for industry. The results showed that the chemical composition differs according to cultivar, which may affect the use of this fruit as raw material for the food industry (Table 3). The moisture content of the quinces studied exceeded those reported by Rodrígues-Guisado et al. (2009) who reported values of 73.11 to $78.46 \%$. Moisture content is of great importance in processing the fruit, with the 'Portugal' showing the lowest content, that is, the highest percentage of dry material, a desirable characteristic for postharvest preservation and processing.

Proteins are molecules that are essential in maintaining the structure and functioning of the organism. Protein content in

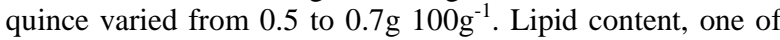
the principal components of food products, is responsible for important nutritional and technological characteristics, and

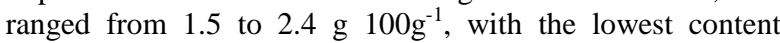
observed in the 'Provence', 'IAC CHA-43' and 'IACCHA13'. Rodrígues-Guisado et al. (2009) reported lipid content similar to those observed in this study, varying from 1.31 to $2.33 \%$. Ash is mineral residue after incineration of the sample. The results obtained show differences between

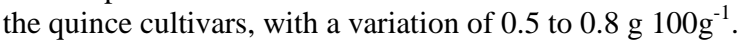

Dietary fiber exercises gastro-intestinal functions through its physical action, hydration capacity and capacity to increase the volume and velocity of fecal matter. It also has the capacity to interact with other dietary constituents through various mechanisms, able to attract greater quantities for fecal excretion. Differences were observed between the cultivars with regards fiber content, with a variation from 1.1

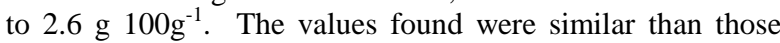
cited by Légua et al. (2013) who analyzed cloned quinces and cited values of 0.93 to $1.63 \%$ of fiber and the content 1.6 $\%$ obtained by Sharma et al. (2011).

Through the process of photosynthesis, sugars synthesized in the leaves are polymerized and stored in the fruit in the form of starch. As the fruit ripens, starch stored in the fruit 
Table 1. Physical characteristics of quince fruits.

\begin{tabular}{|c|c|c|c|c|}
\hline Cultivar & W (g) & $\mathrm{TD}(\mathrm{mm})$ & $\mathrm{LD}(\mathrm{mm})$ & $\mathrm{F}(\mathrm{N})$ \\
\hline Portugal & $139.7 \mathrm{CD}$ & $69.0 \mathrm{AB}$ & $53.4 \mathrm{BC}$ & $72.2 \mathrm{AB}$ \\
\hline Provence & $161.3 \mathrm{AB}$ & $71.7 \mathrm{~A}$ & $60.9 \mathrm{~A}$ & $72.1 \mathrm{AB}$ \\
\hline IAC CHA-43 & $167.3 \mathrm{AB}$ & $70.1 \mathrm{AB}$ & $60.0 \mathrm{AB}$ & 61.7 DEF \\
\hline De Patras & $101.5 \mathrm{E}$ & $60.5 \mathrm{C}$ & $51.2 \mathrm{C}$ & 67.5 BCDE \\
\hline IAC-CHA13 & $68.6 \mathrm{~F}$ & $72.3 \mathrm{~A}$ & $57.9 \mathrm{ABC}$ & $71.6 \mathrm{ABC}$ \\
\hline Mendoza Inta -37 & $175.1 \mathrm{~A}$ & $72.8 \mathrm{~A}$ & $59.9 \mathrm{AB}$ & $70.7 \mathrm{ABCD}$ \\
\hline IAC-CHA48 & $171.4 \mathrm{~A}$ & $73.3 \mathrm{~A}$ & $57.6 \mathrm{ABC}$ & $52.0 \mathrm{~F}$ \\
\hline Smyrna & $148.3 \mathrm{BC}$ & $68.1 \mathrm{AB}$ & $58.8 \mathrm{AB}$ & $60.7 \mathrm{EF}$ \\
\hline Cheldow & $106.2 \mathrm{E}$ & $63.6 \mathrm{BC}$ & $53.2 \mathrm{BC}$ & $79.6 \mathrm{~A}$ \\
\hline Rea's Mamouth & $122.2 \mathrm{DE}$ & $68.4 \mathrm{AB}$ & $50.8 \mathrm{C}$ & $62.0 \mathrm{CDE}$ \\
\hline $\mathrm{CV}(\%)$ & 7.2 & 4.7 & 6.1 & 6.8 \\
\hline LSD & 21.13 & 6.90 & 7.37 & 9.72 \\
\hline SD & 4.43 & 1.45 & 1.55 & 2.03 \\
\hline F test & $64.3 * *$ & $8.1 * *$ & $6.1 * *$ & $15.0 * *$ \\
\hline
\end{tabular}

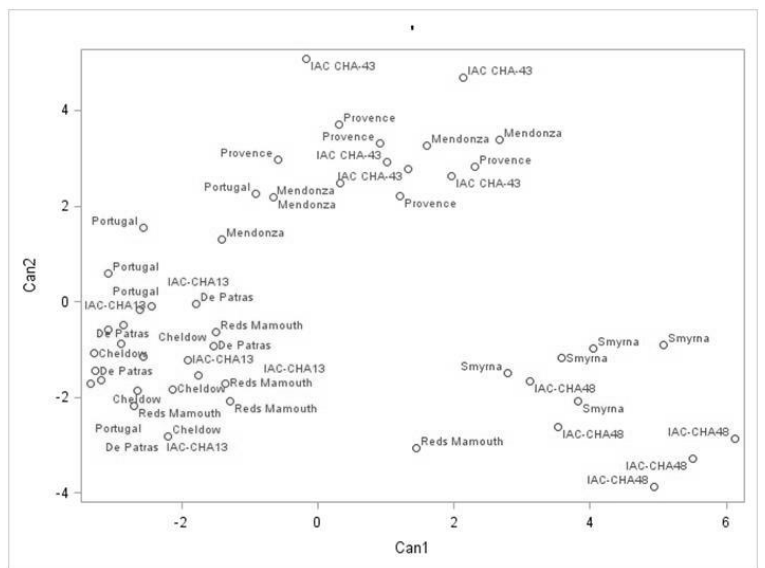

Fig 1. Scatter plot of canonical variables identified by cultivars. Analysis of morphological and physical characteristics.

Table 2. Average results of skin color and pulp of quinces.

\begin{tabular}{|c|c|c|c|c|c|c|}
\hline \multirow[b]{2}{*}{ Cultivar } & \multicolumn{3}{|l|}{ Skin } & \multicolumn{2}{|l|}{ Pulp } & \multirow[b]{2}{*}{$\mathrm{b}^{*}$} \\
\hline & $\mathrm{L}^{*}$ & $a^{*}$ & $\mathrm{~b}^{*}$ & $\mathrm{~L}^{*}$ & $a^{*}$ & \\
\hline Portugal & $73.4 \mathrm{BCD}$ & $-10.4 \mathrm{BC}$ & $57.3 \mathrm{BC}$ & $76.6 \mathrm{CDE}$ & $-1.8 \mathrm{~A}$ & $32.3 \mathrm{~A}$ \\
\hline Provence & $70.6 \mathrm{CD}$ & $-3.3 \mathrm{D}$ & $49.6 \mathrm{E}$ & $78.8 \mathrm{ABC}$ & $-1.1 \mathrm{BC}$ & $32.3 \mathrm{~A}$ \\
\hline IAC CHA-43 & $81.3 \mathrm{~A}$ & $-3.2 \mathrm{D}$ & 53.4 CDE & 78.8 ABC & $-0.9 \mathrm{C}$ & $28.8 \mathrm{~B}$ \\
\hline De Patras & $76.4 \mathrm{ABC}$ & $-5.6 \mathrm{D}$ & $67.3 \mathrm{~A}$ & 76.1 DE & $-1.0 \mathrm{C}$ & $32.2 \mathrm{~A}$ \\
\hline IAC-CHA13 & $68.6 \mathrm{D}$ & $-9.4 \mathrm{C}$ & $51.3 \mathrm{DE}$ & $74.5 \mathrm{E}$ & $-1.2 \mathrm{BC}$ & $35.1 \mathrm{~A}$ \\
\hline Mendoza Inta-37 & 71.2 BCD & $-11.2 \mathrm{BC}$ & $51.3 \mathrm{DE}$ & $80.1 \mathrm{~A}$ & $-1.6 \mathrm{AB}$ & $33.8 \mathrm{~A}$ \\
\hline IAC-CHA48 & $77.8 \mathrm{AB}$ & $-10.2 \mathrm{BC}$ & $57.4 \mathrm{BC}$ & 77.1 BCD & $-1.4 \mathrm{ABC}$ & $32.9 \mathrm{~A}$ \\
\hline Smyrna & $75.2 \mathrm{ABCD}$ & $-12.3 \mathrm{~B}$ & $52.9 \mathrm{CDE}$ & $79.3 \mathrm{AB}$ & $-0.9 \mathrm{C}$ & $32.1 \mathrm{AB}$ \\
\hline Cheldow & $77.5 \mathrm{AB}$ & $-12.0 \mathrm{BC}$ & $60.6 \mathrm{~B}$ & 77.7 ABCD & $-1.4 \mathrm{ABC}$ & $32.0 \mathrm{AB}$ \\
\hline Reds Mamouth & $70.5 \mathrm{CD}$ & $-15.8 \mathrm{~A}$ & $56.0 \mathrm{BCD}$ & $79.3 \mathrm{AB}$ & $-1.7 \mathrm{AB}$ & $33.6 \mathrm{~A}$ \\
\hline $\mathrm{CV}(\%)$ & 4.3 & 13.0 & 4.1 & 1.5 & 19.9 & 4.7 \\
\hline LSD & 6.83 & 2.59 & 4.87 & 2.49 & 0.55 & 3.28 \\
\hline SD & 1.43 & 0.54 & 1.02 & 0.52 & 0.12 & 0.69 \\
\hline F test & $8.0 * *$ & $56.6 * *$ & $26.9 * *$ & $11.2 * *$ & $7.6^{* *}$ & $5.6 * *$ \\
\hline
\end{tabular}

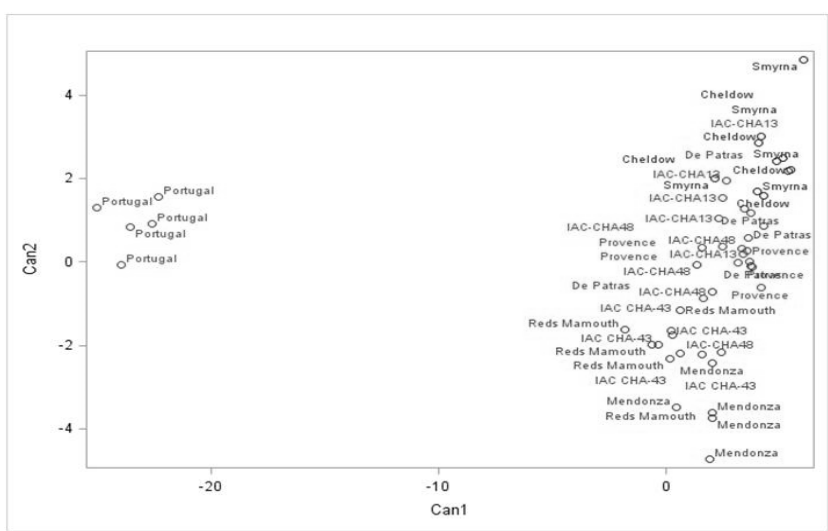

Fig 2. Scatter plot of canonical variables identified by cultivars. Analysis of chemical characteristics. 
Table 3. Average of physical and chemical composition of quinces.

\begin{tabular}{|c|c|c|c|c|c|c|c|c|c|c|}
\hline \multicolumn{9}{|c|}{ 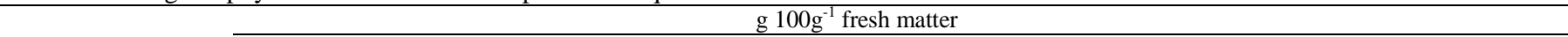 } & \multirow[b]{2}{*}{$\begin{array}{l}\text { Acidity } \\
\left(\text { g galic acid. } .^{-1}\right)\end{array}$} & \multirow[b]{2}{*}{$\begin{array}{l}\text { Soluble } \\
\left.\text { ( }{ }^{\circ} \text { Brix }\right)\end{array}$} \\
\hline & Moisture & Protein & Lipids & Total Fibre & Total sugars & Starch & Ash & $\mathrm{pH}$ & & \\
\hline Portugal & $76.5 \mathrm{D}$ & $0.6 \mathrm{CDE}$ & $2.1 \mathrm{AB}$ & $2.4 \mathrm{~A}$ & $10.7 \mathrm{CD}$ & $5.5 \mathrm{CDE}$ & $0.7 \mathrm{AB}$ & $4.2 \mathrm{~A}$ & $4.6 \mathrm{EF}$ & $14.1 \mathrm{CD}$ \\
\hline Provence & 83.0AB & $0.5 \mathrm{E}$ & $1.7 \mathrm{CD}$ & $2.3 \mathrm{~A}$ & $10.2 \mathrm{E}$ & 4.9 DEF & $0.5 \mathrm{D} 0$ & $4.1 \mathrm{~A}$ & $6.7 \mathrm{BC}$ & $14.5 \mathrm{~B}$ \\
\hline IAC CHA-43 & $81.2 \mathrm{BC}$ & $0.5 \mathrm{DE}$ & $1.7 \mathrm{CD}$ & $1.4 \mathrm{C}$ & $9.5 \mathrm{H}$ & $5.0 \mathrm{DE}$ & $0.5 \mathrm{CD}$ & $3.8 \mathrm{AB}$ & $4.2 \mathrm{~F}$ & $14.9 \mathrm{~A}$ \\
\hline De Patras & $84.0 \mathrm{~A}$ & $0.6 \mathrm{DE}$ & $1.9 \mathrm{BC}$ & $1.1 \mathrm{C}$ & $9.8 \mathrm{~F}$ & $6.7 \mathrm{AB}$ & $0.7 \mathrm{AB}$ & $3.8 \mathrm{AB}$ & $5.0 \mathrm{DE}$ & $14.6 \mathrm{AB}$ \\
\hline IAC-CHA13 & $82.2 \mathrm{ABC}$ & $0.6 \mathrm{BCD}$ & $1.5 \mathrm{D}$ & $2.4 \mathrm{~A}$ & $10.1 \mathrm{E}$ & $6.2 \mathrm{BC}$ & $0.6 \mathrm{BC}$ & $3.7 \mathrm{AB}$ & $6.3 \mathrm{C}$ & $13.9 \mathrm{D}$ \\
\hline Mendoza Inta-37 & $81.8 \mathrm{ABC}$ & $0.6 \mathrm{CDE}$ & $2.0 \mathrm{BC}$ & $1.5 \mathrm{BC}$ & $9.6 \mathrm{G}$ & $4.3 \mathrm{~F}$ & $0.7 \mathrm{AB}$ & $3.6 \mathrm{~B}$ & $4.2 \mathrm{~F}$ & $14.3 \mathrm{BC}$ \\
\hline IAC-CHA48 & $81.3 \mathrm{BC}$ & $0.7 \mathrm{AB}$ & $2.1 \mathrm{ABC}$ & $2.1 \mathrm{AB}$ & $10.6 \mathrm{D}$ & $5.6 \mathrm{CD}$ & $0.6 \mathrm{BC}$ & $3.6 \mathrm{~B}$ & $9.7 \mathrm{~A}$ & $13.1 \mathrm{~F}$ \\
\hline Smyrna & $82.7 \mathrm{AB}$ & $0.7 \mathrm{ABC}$ & $2.3 \mathrm{AB}$ & $2.6 \mathrm{~A}$ & $11.1 \mathrm{~A}$ & $7.3 \mathrm{~A}$ & $0.8 \mathrm{~A}$ & $3.7 \mathrm{AB}$ & $7.1 \mathrm{~B}$ & $13.6 \mathrm{E}$ \\
\hline Cheldow & $82.6 \mathrm{AB}$ & $0.7 \mathrm{~A}$ & $2.4 \mathrm{~A}$ & $2.5 \mathrm{~A}$ & $10.9 \mathrm{~B}$ & $7.3 \mathrm{~A}$ & $0.7 \mathrm{AB}$ & $3.7 \mathrm{AB}$ & $6.3 \mathrm{C}$ & $13.5 \mathrm{E}$ \\
\hline Reds Mamouth & $80.0 \mathrm{C}$ & $0.7 \mathrm{AB}$ & $2.2 \mathrm{AB}$ & $2.1 \mathrm{AB}$ & $10.8 \mathrm{BC}$ & $4.8 \mathrm{EF}$ & $0.7 \mathrm{AB}$ & $3.8 \mathrm{AB}$ & $5.4 \mathrm{D}$ & $12.6 \mathrm{G}$ \\
\hline $\mathrm{CV}(\%)$ & 1.2 & 7.5 & 5.9 & 7.0 & 0.9 & 6.0 & 8.8 & 6.0 & 4.1 & 1.1 \\
\hline LSD & 2.32 & 0.10 & 0.38 & 0.60 & 0.14 & 0.73 & 0.12 & 0.49 & 0.53 & 0.34 \\
\hline SD & 0.15 & 0.02 & 0.08 & 0.13 & 0.03 & 0.49 & 0.03 & 0.10 & 0.11 & 0.07 \\
\hline$F$ test & $107.4 * *$ & $14.1 * *$ & $12.3^{* * *}$ & $17.7 * *$ & $350 * *$ & $47.4 * *$ & $11.7 * *$ & $3.8^{* *}$ & $227.6^{* * *}$ & $101.6^{* * *}$ \\
\hline
\end{tabular}

** indicate significance in an $F$ test at $1 \%$ probability $(p<0.01)$. Means followed by the same capital letters in the column do not differ at $5 \%$ level by Tukey test.

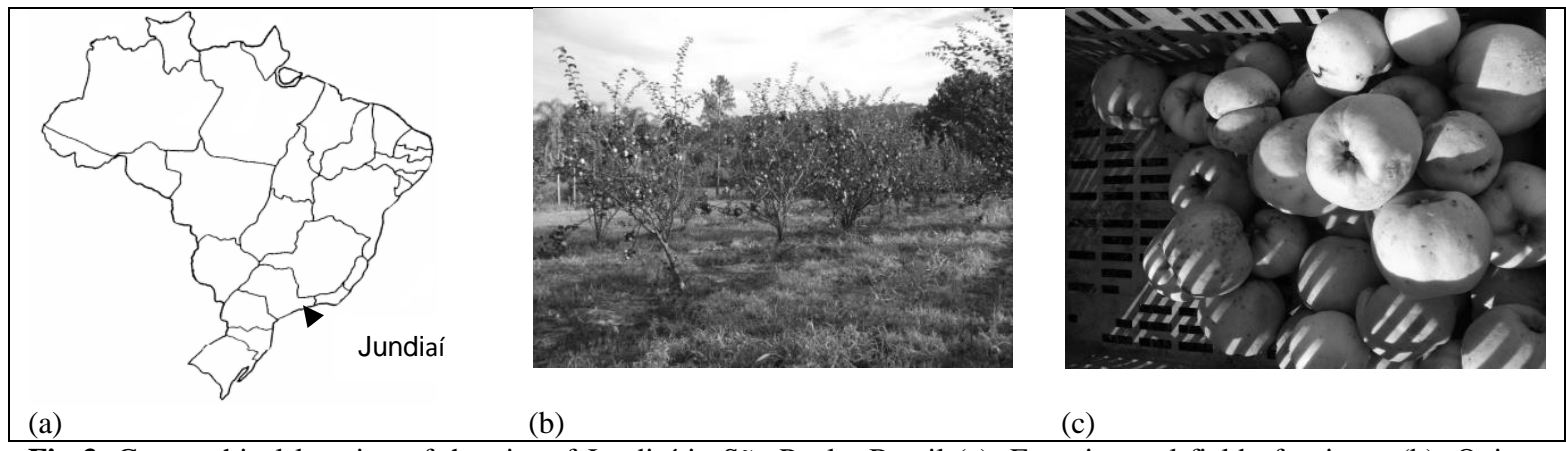

Fig 3. Geographical location of the city of Jundiaí in São Paulo, Brazil (a); Experimental field of quinces (b); Quince fruits harvested (c). 
pulp is hydrolyzed, being transformed into soluble sugars. The starch content of the pulp from quince strains varied

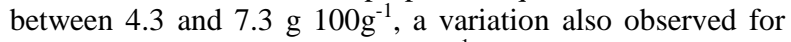

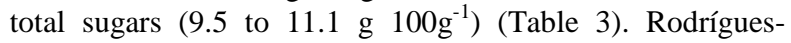
Guisado et al. (2009) analyzing the profile of sugars in quince found levels of 5.31 to $10.89 \%$ for fructose, 4.08 to $5.44 \%$ for glucose, 1.51 to 2.41 of sucrose and 0.31 to $0.42 \%$ for maltose, totaling between 11.67 and $16.08 \%$ total sugars. The higher sugar content cited by the authors may be related to the strain and, mainly, to the ripeness of the fruit. The $\mathrm{pH}$ of the quince varied from 3.6 to 4.2 , results close to the 3.6 to 3.84 reported by Rodrígues-Guisado et al. (2009) and the range from 3.98 to 4.09 related by Szychowski et al. (2014). The acidity level of the quince it mainly represented by the presence of malic acid, the main organic acid in this fruit, as quantified by Rodríguez-Guisado et al. (2009). The titratable acidity of quince varied from 4.2 to $9.7 \mathrm{~g} \mathrm{~L}^{-1}$, with the highest values observed in the 'IAC-CHA48'. These values are in line with what Légua et al. (2013) reported for quince, citing a variation of 5.28 to $9.54 \mathrm{~g} .1^{-1}$ in nine cultivars of quince but higher than values cited by Szychowski et al. (2014).

The soluble solid content for quince varied according to cultivar (12.6 to $\left.14.9^{\circ} \mathrm{Brix}\right)$, a variation similar those observed in studies of Rodrígues-Guisado et al. (2009), Bettiol Neto et al. (2011), Légua et al. (2013) and Szychowski et al. (2014). Flavor is determined by a combination of four basic sensations: sweet, acid, salt and bitter. Sweetness if directly related to sugars and to the sugar/acidity ratio (Alvarenga et al., 2008). The highest values for this ratio were found in the 'Portugal' $(2,33)$, 'Mendoza Inta-37' $(2,29)$ and 'IAC CHA-43' $(2,26)$, which were also those which had a considerable percentage of soluble solids. The lowest value found was for the 'IACCHA48', a characteristic unfavorable for its use in producing sweets. When producing jam, the physic-chemical composition of the fruit has been correlated with the flavor and sensorial acceptance of the products. Alvarenga et al. (2008) comparing sweets produced from different strains of quince found the highest flavor scores for the 'Mendoza' and concluded that this may be due to its low acidity and high level of soluble solids.

The cluster analysis for the chemical composition of quince fruits showed that the 50 cultivar's replicates were separated in $\mathrm{n}=4$ clusters with $10,5,17$ and 18 replicates each.

Multivariate F statistic for Wilks' Lambda was significant ( $p$ $<0.0001$ ); the clusters were well differentiated. Univariate $\mathrm{F}$ was significant for all variables. The most important variable in differentiating the clusters was moisture, followed by starch, lipids and total sugars, with coefficients of determination $\mathrm{R} 2=0.981,0.670,0.554$, and 0.504, respectively. Cultivars in cluster 1 had high values of moisture, starch, lipids and total sugars; cluster 2 contains only the cultivar 'Portugal', with low moisture (Fig 2).

\section{Materials and Methods}

\section{Plant cultivars}

This study used the following cultivars of quince: Portugal, Smyrna, Cheldow, Provence, IAC-CHA48, De Patras, Mendoza Inta 37, IAC-CHA13, IAC CHA 43 and Rea's Mammouth.

\section{Experimental conditions}

The quince were harvested from plants cultivated in Jundiaí$\mathrm{SP}$, at $23^{\circ} 08^{\prime} 53^{\prime \prime} \mathrm{S}$ and $46^{\circ} 55^{\prime} 42^{\prime \prime} \mathrm{W}$, with an mean altitude of 700 meters above sea level. The climate in the region is classified as mesothermic, with a dry winter (Cwa), usually known as altitude tropical, with a mean annual temperature of $21.4^{\circ} \mathrm{C}$ (minimum mean: $15.3{ }^{\circ} \mathrm{C}$; maximum mean: $27.4{ }^{\circ} \mathrm{C}$ ) and annual mean precipitation of $1,400 \mathrm{~mm}$. The soil is shallow and well drained, identified as a Currupira-modal unit (Cur), belonging to the larger Litosol group, phyllite-slate substrate stage (Fig. 3).

The quince trees seedlings were planted in a $3 \times 4 \mathrm{~m}$ space (population density 834 plants per hectare), in February 2005. In 2013 and 2014, as in previous years, they were pruned in winter. They flowered in August 2013 and 2014 and the fruit was harvested in January of 2014 and 2015 (two years). Harvesting began when the color of the fruit's skin changed from deep green to a more yellow-green.

\section{Harvesting and cleaning of fruits}

Healthy fruit were selected, rejecting those that were damaged or rotten, among other defects. Fruit that were totally green in color were rejected. After this selection, five samples with forty five fruits from each cultivar were separated. Fruits from each cultivar went through a sanitation process, washed in running water and immersed in a solution of sodium hypochlorite $\left(10 \mathrm{~mL} \mathrm{~L}^{-1}\right)$ for 15 minutes and then dried on a paper towel.

\section{Analysis of fruits}

The fresh fruits were analyzed for their physical characteristics: weight $(\mathrm{g})$, transverse diameter $(\mathrm{mm})$, longitudinal diameter $(\mathrm{mm})$, firmness $(\mathrm{N})$, skin and pulp color. Measurements of firmness were taken using a texturometer (Stable Micro Systems model TA.XT plus). A needle tip $(2 \mathrm{~mm} \mathrm{P} / 2 \mathrm{~N})$ was used a pre-test speed of $5 \mathrm{~mm} \mathrm{~s}$ ${ }^{1}$, post-test speed $5 \mathrm{~mm} \mathrm{~s}^{-1}$, test speed $2 \mathrm{~mm} \mathrm{~s}^{-1}$; and the depth of penetration was $8 \mathrm{~mm}$. Results were shown in Newton (N). The quince skin and pulp color was evaluated using Minolta CR-400 colorimeter. Results were shown as values $\mathrm{L}^{*}, \mathrm{a}^{*}$ and $b^{*}$, in which $L^{*}$ (luminosity or shine) varied from black (0) to white $(100)$, the values for chroma $a^{*}$ varied from green $(-60)$ to red $(+60)$ and the values for chroma $b^{*}$ varied from blue to yellow, that is, from -60 to +60 , respectively (Chen et al., 2010).

The fruits were also analyzed for its: moisture, protein, fibers, ash, lipids, total sugars, shown in $\mathrm{g} .100 \mathrm{~g}^{-1}$ fresh material (AOAC, 2007), starch determined according to the ISO 6647 (ISO, 1987) methodology, pH, titratable acidity (g malic acid $\mathrm{L}^{-1}$ ) and total soluble solids, determined using a digital refractometer.

\section{Statistical analysis}

The results obtained from evaluating the fruit were subject to variance analysis and means were compared using the Tukey test, with a $5 \%$ level of significance.

A disjoint cluster analysis was performed with SAS 'fastclus proc' on the basis of Euclidean distances computed from the quantitative variables data. The clustering method was the ' $\mathrm{k}$-means model'. The observations were divided in $n$ clusters such that every observation belongs to one and only one cluster. The method assures that all distances between observations in one cluster are lesser than all distances between observations in different clusters. Two analyses were performed, one with the variables of the chemical composition of fruits, where the unit of measurement was $\mathrm{g} / 100 \mathrm{~g}$ of fruit and other with the morphological and physical 
characteristics, with different units of measurements. The method uses algorithms that are sensitive to heterogeneous variances, then it was necessary standardize the variables expressing morphological and physical characteristics before performing the cluster analysis.

The canonical discriminant analysis was performed with SAS 'candisc proc' to summarize between-class (clusters) variation. Univariate F-statistics and multivariate Wilks' lambda statistic were used to discuss the results of the analyses. The significance level was $\alpha=0.05$.

\section{Conclusions}

Quinces differ in their physical, physic-chemical and chemical characteristics, from which it was possible to conclude that the shape of the fruit was globular and oval. The skin color was characterized by the yellow tone and the pulp showed that the fruit has light pulp, of a yellow tone, with some green. The Portugal quince cultivar had the lowest level for moisture, considerable sugar content and a good sugar/acidity relationship, desirable characteristics for heat processing. As with the Portugal, Mendoza Inta-37 and IAC CHA-43 cultivars of quince could also be recommended for use in sweets, jams and syrups among other uses.

\section{Acknowledgements}

The authors acknowledge the financial support of CNPQ.

\section{References}

Alvarenga AA, Abrahão E, Pio R, Assis FA, Oliveira NC (2008) Comparation among marmalades produced from different fruit quince species (Cydonia oblonga Miller and Chaenomeles sinensis Koehne) and cultivars. Ciênc Agrotec. 32:302-307.

Association of Official Analytical Chemists International. AOAC -International. 18.ed. Gaithersburg, 2007. Current Through Revision 2.

Bettiol Neto JE, Pio R, Sanches J, Chagas EA, CIA P, Chagas PC (2011) Production and quality attributes of quince tree cultivars in the eastern of the state of São Paulo. Rev Bras Frutic. 33:1035-1042.

Chen Z, Zhu C, Zhang Y, Niu D, Du J (2010) Effects of aqueous chlorine dioxide treatment on enzymatic browning and shelf-life of fresh-cut asparagus lettuce (Lactucasativa L.). Plant Biol Technol. 58: 232-238.

Fachinello JC, Pasa MS, Schimitiz JD, Betemps DL (2011) Situation and perspectives of temperate fruit crops in Brazil. Rev Bras Frutic. VE:109-120.
Fagundes GR, Yamanishi OR (2001) Physical and chemical characteristics of fruits of papaya tree from 'solo' group commercialized in 4 establishments in Brasilia-DF. Rev Bras Frutic. 23:541-545.

Gunes NT (2003) Changes in ethylene production during preharvest period in quince (Cydonia vulgaris L.) and the use of ethylene production to predict harvest maturity. Eur J Hortic Sci. 68:212-221.

Khoubnasabjafari1 M, Jouyban A (2011) A review of phytochemistry and bioactivity of quince (Cydonia oblonga Mill.). J Med Plant Res. 5:3577-3594.

Koutb M, Morsy FM (2012) Unripe fruit's extract of quince as a potent alpha-amylase inhibitor. J Adv Lab Res Biol. 3:36-41.

International Organization for Standardization (ISO). Norme Internationale: Riz-détermination de la teneur em amylose. S. 1., (1987) 5 p. ISO 66470.

Légua P, Serrano M, Melgarejo P, Valero D, Martinez JJ, Martinez R, Hernãndez F (2013) Quality parameters, biocompounds and antioxidant activity in fruits of nine quince (Cydonia oblonga Miller) accessions. Sci Hortic. 154:61-65.

Pereira GG, Alvarenga AA, Abrahão E, Pinheiro ACM, Oliveira AF, Pio R (2011) Sensory evaluation of japanese quince jam with different concentrations of total soluble solids. Braz J Food Technol. 14:226-231.

Pio R, Chagas EA, Barbosa W, Signorini G, Del Aguila JS (2009) Tests of intergeneric rootstocks for quinces in nursery conditions. Ciênc Agrotec. 33:521-526.

Rodríguez-Guisado I, Hernãndez F, Melgarejo P, Légua P, Martínez R, Martínez JJ (2009) Chemical, morphological and organoleptical characterisation of five Spanish quince tree clones (Cydonia oblonga Miller). Sci Hortic. 122:491496.

Sharma R, Joshi VK, Rana C (2011) Nutritional composition and processed products of quince (Cydonia oblonga Mill). Ind J Nat Prod Resour. 2:354-357.

Silva FG, Oliveira GL (2013) Conhecimento popular e atividade antimicrobiana de Cydonia oblonga Miller (Rosaceae). Rev Bras Plan Med. 15:98-103.

Szychowski PJ, Munera-Picazo S, Szumny A, CarbonellBarrachina AA, Hernández F (2014) Quality parameters, bio-compounds, antioxidant activity and sensory attributes of Spanish quinces (Cydonia oblonga Miller). Sci Hortic. 165:163-170

Wojdyło A, Teleszko M, Oszmian’ski J (2014) Antioxidant property and storage stability of quince juice phenolic compounds. Food Chem.152:261-270. 